\title{
Rock Clubs and Gentrification in New York City: The Case of The Bowery Presents
}

\author{
Fabian Holt \\ University of Roskilde \\ fabianh@ruc.dk
}

\begin{abstract}
This article offers a new analytical perspective on the relation between rock clubs and gentrification to illuminate broader changes in urbanism and cultural production in New York City. Although gentrification is central to understanding how the urban condition has changed since the 1960s, the long-term implications for popular music and its evolution within new urban populations and cultural industries have received relatively little scholarly attention. Gentrification has often been dismissed as an outside threat to music scenes. This article, in contrast, argues that gentrification needs to be understood as a broader social, economic, and cultural process in which popular music cultures have changed. The argument is developed through a case study of The Bowery Presents, a now dominant concert promoter and venue operator with offices on the Lower East Side. Based on fieldwork conducted over a three-year period and on urban sociological macro-level analysis, this article develops an analytical narrative to account for the evolution of the contemporary concert culture in the mid-size venues of The Bowery Presents on the Lower East Side and Williamsburg, Brooklyn, as a particular instance of more general dynamics of culture and commerce in contemporary cities. The narrative opens up new perspectives for theorizing live music and popular culture within processes of urban social change. The article begins by reviewing conventional approaches to rock music clubs in popular music studies and urban sociology. These approaches are further clarified through the mapping of a deep structure in how music scenes have framed the relationship between clubs and gentrification discursively. The article then examines the evolution of The Bowery Presents within the expansive process of gentrification. The focus is placed here on the cultural profile of the now dominant mid-size venue culture and on three stages in the development of the company and its field-structuring impact on rock clubs on the Lower East Side in particular. The conclusion sums up the key points and suggests that gentrification involves changing conditions of artistic creativity and performance, with implications for fundamental aspects of urban life; a point illustrated by the trajectory of Occupy Wall Street.
\end{abstract}

Keywords: Rock clubs, concert venues, gentrification, urban sociology, live music and popular culture, indie rock, music scenes

\section{Introduction}

Although gentrification involves some of the biggest changes in the urban condition since the 1960s, the long-term implications for popular music have received relatively little scholarly attention. While popular music criticism has focused on how scenes have struggled to resist gentrification, this article argues that gentrification needs to be understood as a broader social, economic, and cultural process in which popular music cultures have undergone complex changes. The article focuses on rock clubs because of their central role in this process, both as an avenue of industry development and a space of consumption among new urban populations. The literatures on nodal spaces 
in the city, from nightlife cabarets, theaters, and dance halls (Hannerz 1980: 54; Levine 1988; Nasaw 1993) to markets and fitness gyms (Zukin 1995; Sassatelli 2010) have argued for the social significance of such spaces from a variety of disciplinary perspectives, reflecting different knowledge interests. The contemporary mid-size rock club is a key site for investigating a new popular music culture in New York and its evolution within new populations and cultural industries. It is widely recognized that rock clubs have been challenged by gentrification, but how have they evolved to shape musical performance within the broader transformation of neighborhoods into the condition of generalized gentrification and beyond? The relative lack of knowledge about this process and how it can be studied constitutes a considerable historical and conceptual gap in popular music studies.

A focal point in this analysis is an organization that started promoting rock shows in a small club in the East Village in 1993 and fifteen years later had become the dominant concert promoter and venue operator in the New York metropolitan area, with most of its activities concentrated in mid-size clubs on Lower Manhattan and Williamsburg, Brooklyn, and in larger club venues and concert halls in Midtown and the Upper West Side. The organization's name is The Bowery Presents. Its offices are located in the East Village. In a concert industry context, The Bowery Presents is independent in that it is not owned by one of the two corporate giants, Live Nation and AEG.

At the center of my analysis is the concert culture of the mid-size venues The Bowery Ballroom, Music Hall of Williamsburg, and Webster Hall because they represent the emergence of a distinctive concert culture for new white middle-classes in Lower Manhattan and Williamsburg. Since the mid-2000s, audiences have increasingly come from other neighborhoods in Manhattan, Brooklyn, and New Jersey, and my field research also indicates a growing percentage of tourists from out of town.

The article begins by reviewing conventional approaches to rock music clubs in popular music studies and urban sociology to establish the ground for the analysis presented in the following sections. These approaches are further clarified through the mapping of a deep structure in how music scenes have framed the relationship between clubs and gentrification discursively. The article then examines the evolution of The Bowery Presents within the expansive process of gentrification. The focus is placed here on the cultural profile of the now dominant mid-size venue culture and on three stages in the development of the company and its field-structuring impact on rock clubs on the Lower East Side in particular. The conclusion sums up the key points and suggests that gentrification involves changing conditions of artistic creativity and performance, with implications for fundamental aspects of urban life; a point illustrated by the trajectory of Occupy Wall Street.

The article is based on field research in New York City since 2010, combining participant-observations in venues, interviews with audiences and professionals involved in the scene, music journalism, and hundreds of consumer reviews of venues in the social media applications Yelp and FourSquare. I started by examining individual venues and expanded the analytical field to include changes in production, organization, and neighborhoods in the large-scale process of gentrification, as it became clear how important these aspects were in explaining the venue culture. The main informants were: 1) 70-100 audience members, including casual tourists, frequent local concertgoers, and concert photographers, with whom I had conversations about their experiences in the venues and perceptions of the venue culture and the neighborhood; 2) editors and journalists at The Village Voice, The New York Times, and Brooklyn Vegan; 3) management and record companies working with artists performing in the venues, including Leg Up! Management, We Are Free, Beggards Group, Foundations Artist Management, Pronto Artist Management, The Social Registry, Canvasback Music, Kanine Records, and Lincoln Center. The Bowery Presents declined to participate in interviews from the outset, referring to company 
policy. This was obviously a barrier that made the research on organizational culture and strategy more difficult, but I was able to obtain vital information from a few trusted long-term collaborators when I presented my research to them later in the process.

In addition to accounting for a specific local history, the article has a wider goal of using the case study of The Bowery Presents to illuminate the changing condition of musical and cultural production in the process of gentrification. The conceptual contribution of the article is to develop and illustrate a new analytical approach for understanding live music clubs in such processes of urban change. The main point in this approach is that the analytical focus on the club experience and on particular music scenes in popular music studies can productively be combined with the socioeconomic structural perspective of urban sociology. The argument and findings of the analysis are used in the concluding section to open up perspectives for future research.

\section{Research on Rock Clubs and Gentrification}

Clubs of the pre-gentrified era of the 1960s, 1970s, and 1980s-before the era of generalized gentrification in New York and many other cities (Smith 2002)-have had a privileged status in popular music studies since at least the early 1990s. Thornton's Club Cultures (1995) is one of the most cited books in the field, but the fascination with clubs as a special site of cultural and particularly subcultural performance can be traced back to Hebdige's Subculture (1979) and further back to jazz studies in the 1950s when academic interest in urban music scenes and communities emerged (Merriam and Mack 1960). Although venue culture has not evolved into a distinct area of study, but has mostly been part of studies of music scenes, the pre-gentrification era rock club is a powerful figure among fans, critics, and scholars; a fact that should not be underestimated.

Small clubs had a unique role as nodal social institutions in New York's popular music cultures such as rock, electronic dance music (EDM), hip hop, and salsa in the era before generalized gentrification. ${ }^{1}$ Small clubs were sites of vibrant social and artistic interaction, experimentation, and innovation. More than being meeting places and providing work for musicians, club scenes were catalysts and arteries in this seminal period of the aforementioned genres (Charnas 2010; Gann 2006; Gendron 2002; Lawrence 2004; Reynolds 2005; Washburne 2008). Among many influential examples are rock clubs such as CBGBs, the Bottom Line, Wetlands Reserve; clubs for experimental music and jazz such as the Knitting Factory and Tonic; EDM party clubs such as the Loft, Studio 54, Danceteria, and the Roxy; hip hop clubs such as 371 and the Fever in the Bronx; and salsa clubs such as Cheetah and the Corso. These clubs have become the stuff of legend, as reflected in the attention they continue to receive in music criticism, and in the attempted historical landmark designation for CBGB's building, for instance (Methos 2005; Shulman 2005).

The following section provides evidence of negative associations with gentrification, but let us first acknowledge two further reasons for the relative lack of interest in clubs of the gentrified era. One is the decline of the experimental and subterranean cultures that have been central to popular music studies, from studies of punk and hip hop to studies of electronic dance music (e.g., Hebdige 1979; Shank 1994; Rose 1994; St. John 2009; Garcia 2013). While popular music has also been studied as "music for pleasure," to invoke Simon Frith, the field has been structured by powerful discourses of what is perceived to be culturally relevant within cultural scenes and the media. In this perspective, the contemporary popular forms of indie rock might initially seem to be merely a commercial evolution of something that was more artistically and socially relevant in the 1980s and 1990s. Commerce and consumption are indeed important dimensions of this culture in which live music performance has evolved into larger venues and festivals to become highly structured by the commodity market of concerts and by professional ticketing and venue services. In its contemporary commercial forms, produced as a kind of niche "luxury" popular culture commodities within an 
industry network of companies such as The Bowery Presents, The Windish Agency, and Pitchfork.com, indie rock is no longer a community-based culture, and its dominant urban form is no longer a social scene with utopian aspirations. However, live music venues in the gentrified neighborhood are still sites of performance and experience, and they reveal important aspects of culture and commerce in contemporary cities.

The second reason for the relatively limited research interest in clubs is that they might have lost some of their functions in the age of digital networked media. More music discovery, consumption, and participation is happening online, and the spaces of production have migrated away from pricey city zones to more remote areas and into digital worlds. Music production and communication have become spatially decentralized, and a great deal of communication about new music happens in the blogosphere and in social networking sites. Moreover, more individualized consumption is made possible by a wide range of applications that deliver recommendations of concerts based on user-generated data, including Songkick, Last.fm, and YouTube. The blogosphere played a big role in discovering and promoting the now popular forms of indie rock. Many know about the mainstreamification of indie rock in the 1990s, involving a shift from noise aesthetics to more conventional rock and pop singing, lyrical elegance, and dance-friendly grooves, and from bands with an anti-commercial stance to bands licensing their music to car commercials, for instance (Abebe 2010; Albini 1993). Little is known, however, about how a new generation of indie artists and audiences are shaped by the gentrification of New York neighborhoods. My informants, including managers of prominent bands such as Beach House and Animal Collective, routinely attributed importance to the internet in creating audiences, and they talked about how bands from around the country look to New York as a destination once they have achieved some level of success. ${ }^{2}$ All of the informants, however, noted that networking in the city and, above all, playing shows is still essential in the learning curve and in the further promotion of bands. ${ }^{3}$ Clubs have not lost these functions and therefore still deserve scholarly attention.

Before analyzing clubs in the process of gentrification, it is important to acknowledge how conventional wisdom of live music clubs has evolved in popular music studies. Research on clubs in popular music studies falls within the area of music scene studies and often originates in graduate student fieldwork in small clubs. The concept of scenes survives criticisms and competition from other concepts of collectivity (Hesmondhalgh 2005) to frame clubs as sites for community experience and nodes in networks of audiences, media, and producers. Influential contributions to this literature include the early work of scholars such as Berger (1999), Cohen (1991), and Shank (1994). Later work by Fox (2004) and Washburne (2008) illustrates developments in ethnographic approaches to understanding the culture of small venues in community perspective.

While conventional scene and community approaches to clubs remain useful for understanding performance and collectivity in small clubs, they do not account for the changing role of venues in processes of urban change or of mid-size venues. In particular, the focus on small clubs (e.g., 100-300 capacity) is no longer tenable when mid-size venues (e.g., 500-1500 capacity) are becoming increasingly dominant in New York and other cities because of changing market conditions. ${ }^{4}$ This shift of emphasis toward larger club venues has deep implications for production and experience. The big crowd in mid-size venues is generally drawn to a headliner and thus has a more targeted interest in the concert itself. Such a crowd is also too big for extensive socializing and informal networking inside and outside the building.. In my ethnographic experience, moreover, the large crowd could generate more powerful responses and a feeling of greatness, but also be less sensitive, and there were fewer and less personal encounters between strangers in the audience. Comparing The Bowery Ballroom with a small DIY show, an experienced insider found a higher degree of community ownership and trust in the latter: "A DIY show feels more like a house party," he said. 
"You don't go up to someone at The Bowery [Ballroom] and say "Hey, how's it going?" (Ariel Panero, personal communication, 23 April 2010).

Sociological studies of the cultural dimension of gentrification, on the other hand, have paid little attention to evolutions in rock clubs and concert venues more generally. Influential early studies such as Zukin's (1982 and 1995) investigated how more official cultural spaces such as museums, squares, and parks, for instance, were being influenced by privatization and corporate marketing. With a core example in Disney World, Zukin explored new forms of social control through visual-architectural ordering, theming, and cleaning. Later studies adopted insider perspectives among the new urban middle-classes and creative industry workforce (Florida 2002 and 2005; McRobbie 2002; Lloyd 2006; Currid 2007; Grazian 2008). This literature brings more attention to upscale bars, restaurants, fashion, design, and electronic dance music clubs, for instance, but little has been written on clubs where audiences come primarily for the musical experience or how gentrification has shaped the culture of live performance in rock music venues. One of the few sociological studies that views live music clubs as more than a driver of gentrification in the early stages of the process is Grazian's study of blues clubs in Chicago (2003). His study sheds light on changing geographies and histories of live music consumption and its intimate relation with a search for authenticity in urban nightlife. The present article examines the same thematic in a different case study and illustrates how the social process perspective can explain both evolutions in venue culture, organizations, and the discursive and historical framing of changing music scenes and their relation with the gentrification of neighborhoods more generally. Cohen's more recent work (2007) approaches gentrification as a theme in the history of a city's popular music heritage. At a more general level, a large body of social science research has studied many aspects of the general process of gentrification, from strategies of urban renewal to structural changes in demographics, economies, labor markets, and the emergence of new ethnic-racial geographies (Smith and Williams 1986). To a lesser extent, sociologists have also studied the relation between gentrification and cultural consumption and social aesthetics in the urban environment, including the overall shift from "gritty" to "cool" (Zukin 2010). However, studies of music and gentrification have been few and far between, and those mushrooming at conferences these years still tend to be histories of particular scenes. There is a lack of more systematically organized analytical narratives of evolutions in urban musical life in the process of gentrification. Evolutions in venue culture illustrate significant changes in consumption, business, and neighborhood dynamics within the new and generally more commercially developed urban cultural landscape.
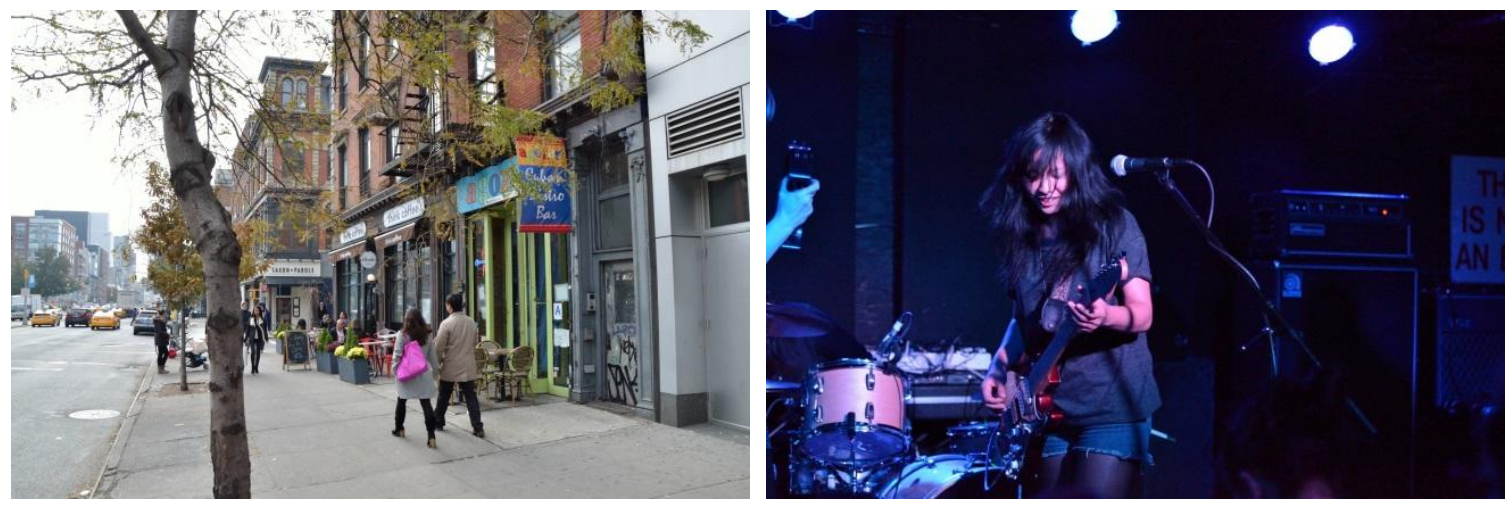

Figure 1 (Left) A sidewalk view of The Bowery by Think Coffee, one of the popular establishments in this area of the gentrified Lower East Side. Think Coffee is a gourmet mini chain concentrated in Greenwich Village, and this shop opened in 2008.

Figure 2 (Right) One of the many Brooklyn baby bands in action at Mercury Lounge 


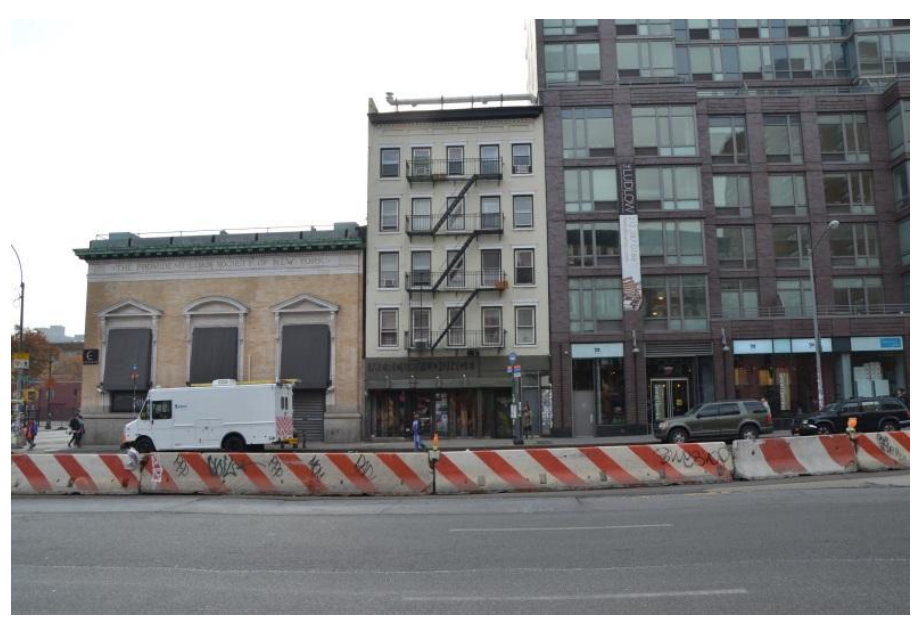

Figures 3-4. Street views on Houston Street show how Mercury Lounge is dwarfed by The Ludlow, one of the major high-rises on the Lower East Side. The Ludlow opened in 2007.

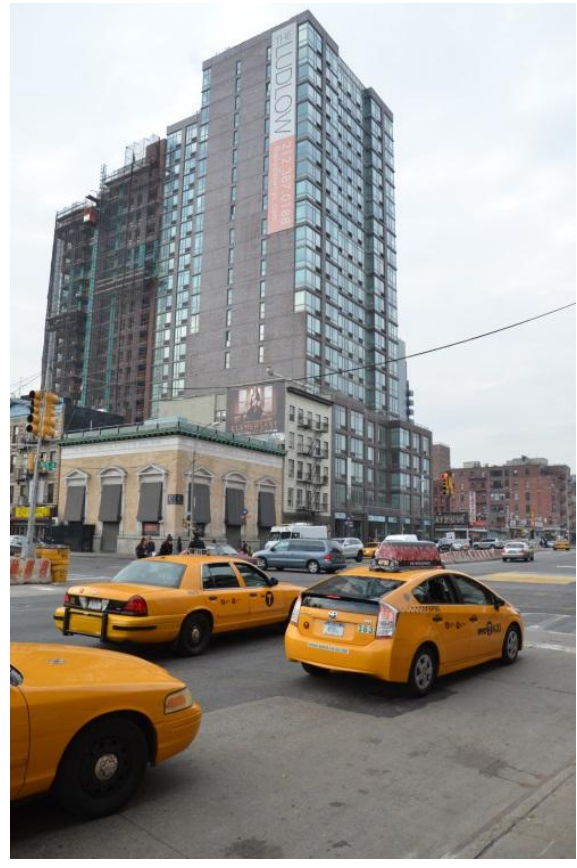

\section{From Outside to Inside Gentrification: The Decline of a Scene and the Beginnings of a New Concert Market}

Among rock fans, artists, and music critics, gentrification commonly has negative connotations. It is associated with commodification, standardization, and popularized luxury products sold in design-intensive retail environments of chain stores such as Starbucks, the Banana Republic, and Whole Foods Market. While these corporate brands dominate Midtown and can be found in almost all areas of the city, areas such as East and West Village are also characterized by more specialist and upscale mini chains catering specifically to self-conscious urban populations. In the desire to retain a sense of urbanism, popular images of gentrification are perceived as a kind of suburbanization with reference to nation-wide chain stores and mass culture (Hammett and Hammett 2007; Lloyd 2006; Zukin 2010). Gentrification, moreover, also carries negative connotations because of the pricing out of not just artists and arts spaces, but also of low-income residents more generally. White middle-class dominance has been a defining characteristic since gentrification was first recognized in the mid-1960s (Sassen 1991; Smith and Williams 1986; Terkel 1967). In New York and other cities, this has culminated in an increased homogeneity of entire neighborhoods (Atkinson and Bridge 2005; Keith 2005; Shaw 2007). The number of blacks and Hispanics increased in New York in the decades after 1960, but there was a decentralization of those population groups from Manhattan to the outer boroughs (Abu-Lughod 1999: 299). The black population constituted 36 percent in Manhattan in 1960 and only 15 in 1990, and it has remained essentially the same ("Demographic Profile Data 2010"). More specifically, high levels of displacement occurred on the Lower East Side between 1980 and 1990, with a 14.5 percentage drop in the Hispanic population and a corresponding growth of residents over 25 with a college degree (Mele 2000: 250). ${ }^{5}$ To give a sense of how the broader New York underground scene has come to view gentrification, consider the following reactions to the closing of Tonic in East Village. This is the beginning of a thread in the Flickr group "experimental LIVE music" started by the user digital_freak:

Sad sad sad news for the avant-garde music scene in New York (and beyond) as its most vital and eclectic sanctuary is about to disappear !!! It's now official: the legendary club TONIC will close its space in the Lower East Side in April 2007. Another proof if needed 
of how hard it is to promote, support and live from experimental music even in major cities...

Below is the blurb from the Tonic website (http://www.tonicnyc.com/) [...] I urge you to show up for the last gigs ever at 107 Norfolk if you can, to send emails and basically to show some LOVE !!!

Dear Musicians, Fans and Friends:

After more than 9 years as a home for avant-garde, creative, and experimental music, Tonic will reluctantly close its doors on Friday, April 13th, 2007. We simply can no longer afford the rent and all of the other costs associated with doing business on the Lower East Side.

The neighborhood around us has been increasingly consumed by "luxury condominiums", boutique hotels and glass towers, all making the value of our salvaged space worth more then our business could ever realistically support. We have also been repeatedly harassed by the city's Quality of Life Task Force which resulted in the debilitating closing of the ))sub((tonic lounge in January. Coincidentally, this campaign began as our immediate neighbor, the Blue Condominium building - a symbol of the new Lower East Side - prepared to open its doors.

[...] If profit had been our chief motivation we could have changed our programming to something more mainstream and financially lucrative. Instead we were more committed to a certain type of music and loyal to the community that supported us.

Sincerely,

Melissa and John

("The end of TONIC...." 2007)

The above excerpt of a long thread illustrates a deep structure in the framing of gentrification in music scene discourse of the pre-gentrified era. In this discourse, small performance spaces take on a central role, particularly clubs engaging in community and artistic experimentation such as Tonic. The club is described as a "legendary" "sanctuary" for the "community," with managers resisting to give in to "mainstream" tastes for "commercial" reasons. The letter from the managers expressing their personal feelings to artists, fans, and friends in terms of solidarity and the "heroic individual vs. the system" metaphor are also typical elements of such discourses on gentrification, which surfaced in responses to the closing of other clubs and police interventions in the Brooklyn DIY scene. ${ }^{6}$ In contrast, the dominant rock clubs of the contemporary Lower East Side, exemplified by The Bowery Presents, are circumscribed by a concert business discourse centered on professional artists and the professional presentation of these artists. The company's website describes each act with no sign of the informal language and insidership characteristic of underground and DIY live music promotion. The notions of neighborhood and community are not part of the company's discourse. The Twitter stream of The Bowery Presents occasionally addresses readers as fans, but not as friends, and there is no mentioning of individual managers. Moreover, the service in the venue itself is perfected and optimized compared with rock clubs of earlier decades, with better sound, air conditioning, cleaning, and precision in the presentation of acts each night, all of which improves the quality of experience from a consumer culture perspective to sustain a particular urban middle-class concert culture.

The negative associations with gentrification might explain why urban cultural circles tend to see it as an external evil, inventing a discursive location outside of the process through a set of dichotomies, as illustrated by the quotation above. The first step toward analytical knowledge is acknowledging the existence of the narratives and understanding how they evolve from particular cultural and historical formations in the city's rock scene. It is common knowledge among observers of the scene that 
legendary clubs of the 1970s and 1980s closed in the late 1990s and early 2000s, including CBGBs, the Bottom Line, and the Knitting Factory. Yet, there is not a reflexive awareness of changing narratives and their social dimension. Even astute observers gloss over the transformations in statements such as this: "There are no reliable statistics about the flux of the quantity of clubs over the years, but in general the ashesto-ashes principle applies: when one closes, another opens" (Sisario 2006). ${ }^{7}$ The remainder of this section highlights the development of rock clubs in the 1970s and The Bowery Presents on the Lower East Side of the 1990s to highlight two social formations central to current narratives and transformations.

Small rock clubs proliferated on the Lower East Side during the economic crisis in the 1970s when young artists concentrated in post-industrial spaces. There was an economy of low rents, bars with inexpensive beer, low costs for cleaning and security, and spaces where musicians could hone their skills, experiment, socialize, and party. By all accounts, the punk, no wave, and downtown Manhattan clubs of this era evolved as much from the larger urban social environment as from the agency of club managers. In the case of CBGB, for instance, owner Hilly Kristal at first wanted to present country music, but the place ended up becoming a nodal point in the emerging punk scene, in part because artists in the neighborhood started hanging out there when it opened in 1973 and had few places to play in the neighborhood (Kozak 1988: 13-16). Kristal realized that this was a niche he could exploit, however. The many small rock clubs that emerged in the following years formed a breeding ground for a social scene shaped by the dirty, noisy streets and their post-industrial architecture, as well as by drugs and crime. O'Meara offers a compelling interpretation of the relation between the neighborhood environment, noise aesthetics, and clubs, drawing inspiration from soundscape theory (2007). These underground and downtown clubs might have stimulated gentrification, but it was the SoHo arts scene that had the most direct role as a driver of the first intense cycle of gentrification on Lower Manhattan (Zukin 1982).

The rock scene of the 1970 s and 1980s generally did not adapt to gentrification. Instead, parts of the culture migrated to Brooklyn in the early 2000s when the costs of operation had increased dramatically (Lee 2002). New venues such as Galapagos, North Six, and Club Luxx opened in Brooklyn, but the center of action in this scene was in loft and warehouse spaces, not venues. Promoter Todd Patrick pioneered a new kind of underground DIY scene in lofts, warehouses, and other unconventional venues without a license. The shows were often promoted by word of mouth and simple web pages before the scene caught fire in the blogosphere, before the influential blog the Brooklyn Vegan even existed. To many younger musicians, who valued experimentation and community participation at a time when Manhattan had become a place for mid-size venues with headliners, this Williamsburg warehouse scene became the epicenter of the rock scene in the 2000s (Jim Sykes, personal communication, 15 May 2012; Beck 2012). Around 2010, however, this scene was already decimated by rapid gentrification. Important spaces such as Market Hotel and Monster Island Basement (McKinley 2012) closed, and the free concerts in McCarren Park's pool were replaced by ticketed events promoted by the corporate giant Live Nation (Sisario 2008). The free "Jelly pool shows" that started in 2005 moved to the Williamsburg waterfront in 2009, attracting a much larger audience, corporate sponsors, and celebrities such as Jay-Z and Beyonce. ${ }^{8}$ In short, the Manhattan underground inspired a new scene in Brooklyn, but one that quickly transformed.

The Bowery Presents opened its first club, Mercury Lounge, in the Lower East Side in 1993 when gentrification had reached an advanced stage in SoHo and started to surface in this area, too. With an audience capacity of 200 people, Mercury Lounge is small, and there is nothing fancy about its architectural design. The audience walks directly into a small bar to enter the only other room for patrons, the showspace, which feels a bit like a garage because it is simply an empty room with a low stage. The space was a former tombstone store, and the interior is kept basic, but it is clean, air- 
conditioned, and it has great acoustics and an excellent sound system. A resident who lived almost in the backyard from the club for over ten years remembers that college and post-college graduates had started to move in and new places were opening up to serve this new population, including bars where people would hang out on the weekends. Mercury Lounge was part of a web of small rock clubs in the East Village area, including Brownies and Pyramid, and The Spiral just across the street (Bill Bragin, personal communication, 30 March 2012). As Mercury Lounge started to gain attention as a place where talented new young bands emerged, the club pushed the boundaries of the scene further down toward the Lower East Side.

During the five years that The Bowery Presents only had Mercury Lounge, the management tested and developed relationships with a large number of "baby bands" of a new generation. ${ }^{9}$ Like CBGBs and Brownies, Mercury Lounge became an important place for new and talented rock bands to appear on a bill with 4-5 bands per night, totaling about 1,500 bands a year. This model allowed The Bowery Presents to take chances on bands and develop a core expertise in the evolving indie rock scene in New York before these bands gained mainstream popularity in the early 2000s. Some of the most well-known bands are those associated with the so-called class of 2001/2002, including the White Stripes, Yeah Yeah Yeahs, The Strokes, and Interpol (Phillips 2007; Goodman 2013). In short, Mercury Lounge was and still is a "feeder club" from which The Bowery Presents grow relationships with artists before they perform in the larger venues. ${ }^{10}$
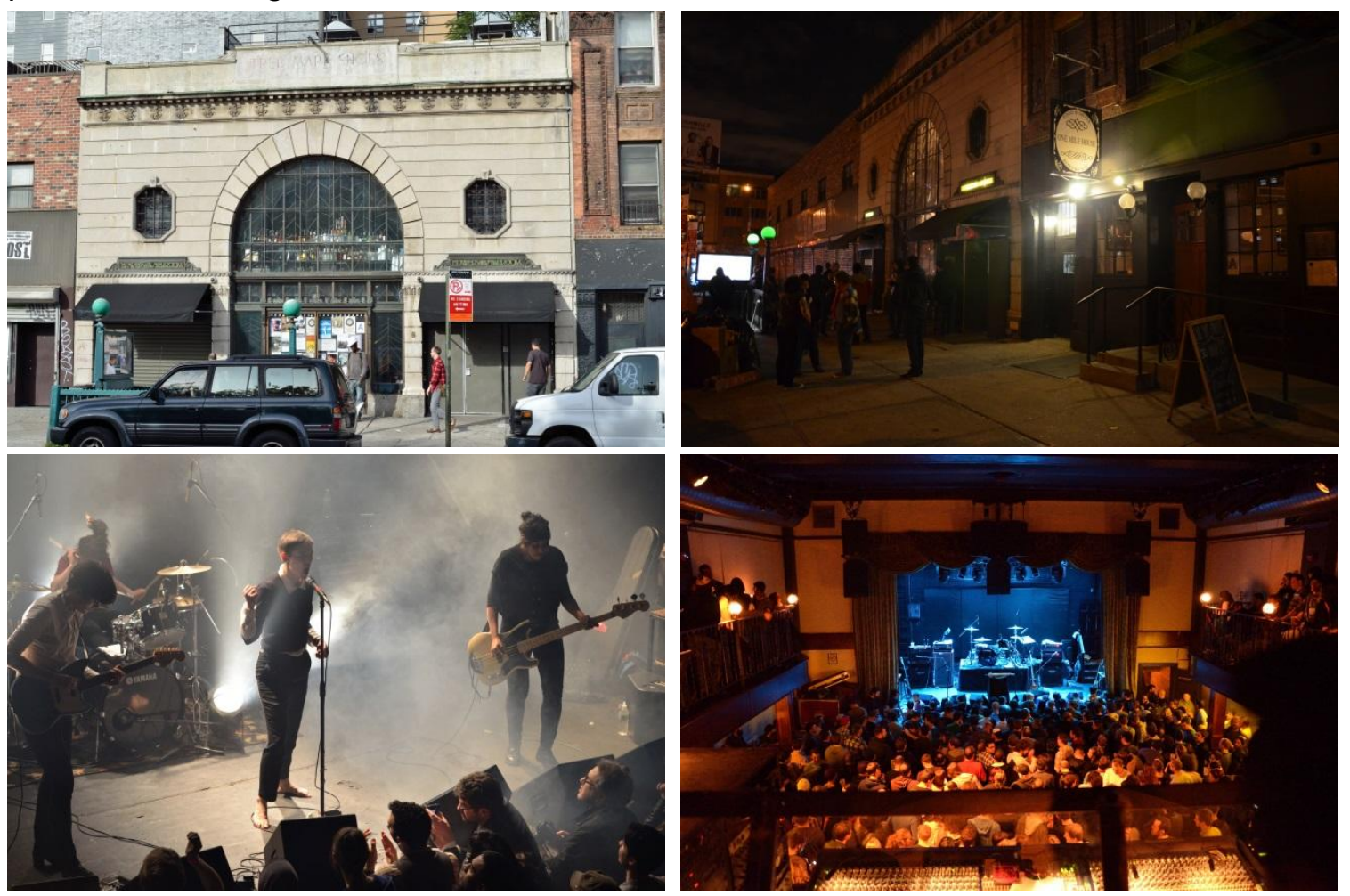

Figure 5-8 (left to right, top to bottom). Exterior and interior shots of The Bowery Ballroom. The Savages performed as a headliner act on March 24, 2013. 

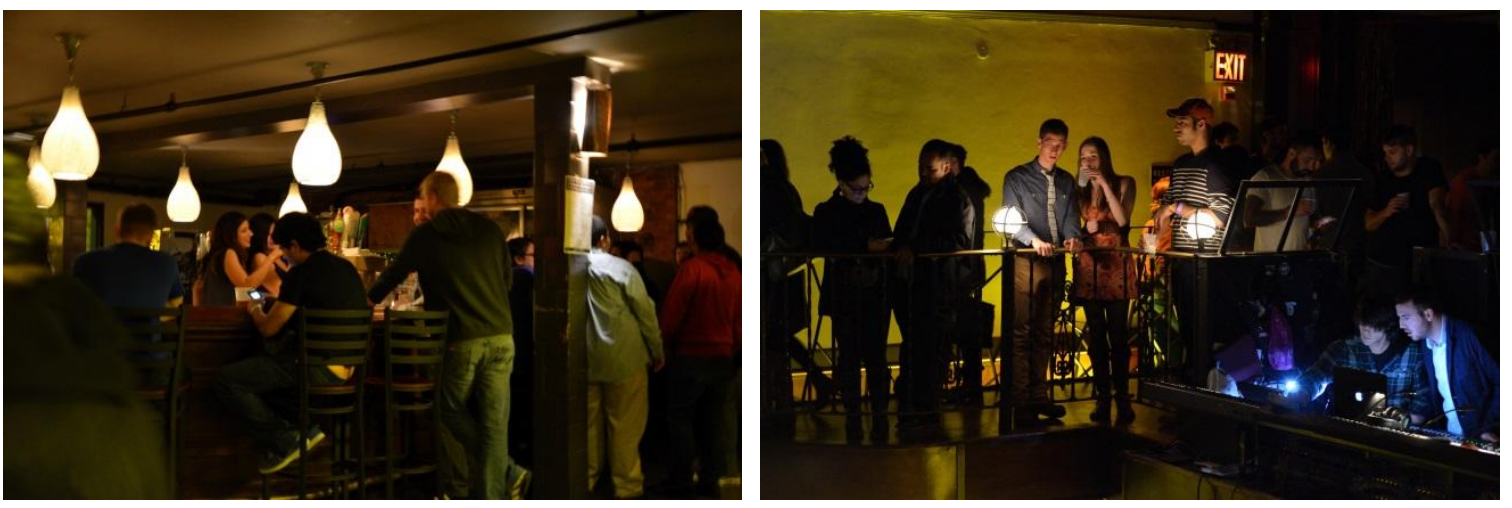

Figure 9 (Left). Intimacy in the lounge bar of The Bowery Ballroom. Figure 10 (Right) Intimacy in the balcony

\section{The Bowery Ballroom: The Cultural Profile of the New Mid-Size Venues}

As some of the successful bands started to gain wider attention, instead of leaving them with the only option of going to other promoters The Bowery Presents opened a larger club, The Bowery Ballroom, so that bands could graduate inside the organization's orbit. This business practice was later extended to large theaters and arenas. ${ }^{11}$ The 700-capacity Bowery Ballroom opened in late 1997 as the first mid-size rock club in the area, larger than the 400-capacity Bottom Line in nearby Greenwich Village. The location on Delancey and Bowery can be seen as a strategic entrepreneurial decision because it was the first venue of its kind in the gentrifying neighborhood and before possible competitors did the same. A similar strategic move characterizes the company's opening in 2007 of Music Hall of Williamsburg and of the United Palace in Washington Heights. Moreover, these venues are well connected via subway stations, making them conveniently accessible for audiences in other neighborhoods.

The Bowery Ballroom is not a place associated with utopian alternatives to gentrification or dominant society. In this sense, The Bowery Ballroom represents a culminating point in the transition from punk to gentry, from underground to on-theground venues, from basements and backyards to the ground floor and formal concert spaces with the generic element of the notion "venue" as a standardized distribution space created from industry design templates. Moreover, one can argue that The Bowery Ballroom presents an adaption to the tastes and lifestyles of the new population. For example, the music programming appeals to popular tastes, while having an indie aesthetic that generates social distinction and an aura of contemporary cool (Sisario 2007). The high-quality audio-visual technology helps create a comfortable, safe, and perfected environment along with the social behavior of the audience. In contrast to the subversive hedonism of pre-gentrified club cultures, this is a public culture shaped by career consciousness, commerce-based leisure, and the poetics of self-discipline in the culture of the gentry, also reflected in the commercial, professional venues for fitness and health (Sassatelli 2010). This culture is shaped by the changing conditions of urban life, particularly the conditions of a more unstable labor market and rising costs of living. Another factor that cannot be observed directly in the venue experience itself is the industrial organization of the mid-size venues of The Bowery Presents and its relative monopoly in a new concert market of popular indie rock. To develop this analysis, I offer an outline of three key characteristics of the venue culture that might prove helpful in future studies:

a) An Urban Indie Aesthetic for a Semi-Specialist Audience

The music programming evolved from the focus on small rock bands at Mercury Lounge to more professional headliner acts. The mid-size venues are headlineroriented and attract more casual music consumers and tourists. In the early years of 
The Bowery Ballroom, it was perceived to be cool in neighborhood circles and some of my informants remembered it as a place for hipsters, mentioning that one of the first artists that played there was P.J. Harvey. Today, many of those people have moved to Brooklyn, and the mid-size venues do not have the same aura of cool and generally attract more people from other neighborhoods. Based on my field experience, a significant percentage of the audiences are tourists, but there is also a local audience and a group of passionate fans that go to concerts $3-5$ times a week. One characteristic of the audience culture is that many arrive late and wait for the main act to begin, while some get to the showspace during the last of the two opening acts simply to get a good spot. There are many couples and peer-groups of $3-5$ persons, and there is often a lead fan in the group who knows that band and hears about the show from popular indie blogs such as Pitchfork and middle-class media such as New York Times, Time Out, and NPR. The lead fan is typically a semi-specialist consumer and not so specialized that he or she explores new music for hours every day on obscure indie blogs.

The music programming of the mid-size venues is characterized by an emphasis on artists with original compositions, band collectivity, stylistic sophistication, and other aspects commonly associated with indie aesthetics, including lyricism, dance-friendly grooves, and emotional states that are generally more positive than in the punk-derived early indie rock. The music is generally not characterized by experimental and aggressive sounds when compared with the Brooklyn warehouse scene. There are many contemporary indie rock bands with pop sensibilities such as Animal Collective, Arcade Fire, Beach House, Dirty Projectors, The Joy Formidable, St. Vincent, Yeasayer, and Yeah Yeah Yeahs. (Some of those bands have already migrated to larger venues, but are mentioned here to indicate the musical profile of the venues for a broad readership.) There are also more pop-oriented indie bands and some with roots in electro rock and disco. Occasionally, The Bowery Presents also presents bands with little or no relation to the indie aesthetic that remains a marker of the company's music profile and role as urban tastemaker. Recent examples of this include the boy band sound of Ed Sheeran and the commercial house music of Rudimental.

The indie aesthetic can also be traced in other prominent styles of "roots" and singer-songwriter music. For instance, the programming of what I call "roots" music is a key component and interesting because it builds on the history of professional performances of folk and rural music that goes back to New York's folk revival in the 1950s and beyond. Roots music here denotes music that draws on folk and rural traditions such as country music, gospel, and bluegrass, but is performed with a sense of contemporary urban sophistication. The pastoral and exotic approach to the rural in the 1950s has faded, and the boundaries between rural and urban are often fluid. Many younger people at the shows have moved fairly recently to New York to study or work, and there are many tourists from other cities. Neither audiences nor artists articulate a specialized identity such as hipster behavior or slang. This suggests a less intense urbanism according to the subcultural theory of urbanism (Fischer 1995). However, the venues are located in areas that are revered in narratives of the New York experience among the new white middle-class populations, including artists and audiences in these venues. The mid-size venues are surrounded by the same authenticity in the blogosphere as Brooklyn DIY spaces but they instead have a more central place in the mainstream image of "New York - Brooklyn indie rock" (e.g., Sisario 2007). Urban values are also reflected in responses to the stage persona of the artists. In March 2012, for instance, I experienced a country music duo from the South appealing to the audience at Mercury Lounge with an image of rural authenticity, but a similar band received a less positive response when it performed as an opening act at the mid-size venue Webster Hall a few days later and expressed an everyday rural experience without adapting to a professional performer persona expected from a headliner. 
b) Optimized Venue Facility With a Semi-Corporate Identity

In terms of acoustics and audiovisual technology of reproduction, the mid-size venues of The Bowery Presents can be viewed as a culminating point in the evolution of clubs for rock concerts. The managers have no doubt experienced poor sound and air condition in other clubs over the years and tried to optimize the facilities when creating these venues. They have improved material and technological functions to create a more professional service environment for concerts. However, this does not necessarily improve the social experience of a rock show or strengthen the relation between the scenes and the neighborhood. Some insiders of the Brooklyn DIY scene find the venues a bit sterile, but most audiences I talked to do not understand this criticism and instead find them pleasant, well designed for the purpose, and conveniently located. For instance, an architect and a lawyer made the point that they could not hang out in a remote club in Brooklyn until four in the morning because they had to go to work the following morning. They also did not have nostalgic or romantic feelings about the gritty environments of the Lower East Side and its rock clubs in previous decades. One insider said that audience sociability is integrated in the design of the bars of The Bowery Ballroom and the Music Hall of Williamsburg. In those two venues, the audience enters through the bar in the basement that is designed as a lounge in which patrons can look at other patrons across the room. However, another insider, a regular concertgoer and music journalist, felt that these bars were just like airport room, with audiences waiting for the headliner. The significant differences between underground clubs and mid-size venues reflect, in my view, the creation of neutral spaces that are comfortable for and appealing to middle-class aesthetics.

The organizational identity of The Bowery Presents shapes the venue culture. The organization communicates with a passive voice typical of corporate communication, as indicated above, and it has a logo, but the organization's identity is kept discreet, and each venue has a unique name rather than a franchise name. All of this suggests that its audiences perceive the relation between the concert and the venue with the artist at the center and the venue as a provider. The Bowery Presents, moreover, is positioning itself as an independent promoter without the corporate franchise approach of the House of Blues, for instance, only to sustain its urban niche identity against the mainstream, suburban connotations of the latter. Further research could explore audience attitudes and how venues institutionalize the consumption of live music as professional art, rather than street and community art.

\section{c) Capitalist Entrepreneurialism}

The capitalist entrepreneurialism of The Bowery Presents is evident from the above descriptions of strategic investments and decisions about the location of the venues. Entrepreneurialism is a defining feature of mid-size venue culture because it would simply not exist without it, and it has evolved along with a growing indie rock industry network of organizations, particularly Pitchfork.com, The Windish Agency, and indie labels within major record companies such as Rounder and Canvasback Music. There is an instrumentalist rationale in the business practices of the organization, including a) the development of relations with artists in a career perspective and b) the progressive expansion into more and larger venues in strategic locations to exploit the market potential of artists, with a degree of market monopoly as a result. Many professionals I interviewed said that The Bowery Presents was essential to their business, and at least a few of them wished for more alternatives.

\section{Three Stages in the History of The Bowery Presents and the Field of Rock Clubs}

The field of Manhattan rock clubs cannot be neatly divided into time periods, but there are stages in the development of The Bowery Presents that give a perspective from which to consider general changes in this field. The historical complexity is so that 
a "factoring out" of the process (Becker 1998) would easily obscure how the factors change over time. The growing monopoly of The Bowery Presents and the scale of its business, for instance, create a new market structure and thus change the conditions of the field.

The development of The Bowery Presents and the field can be viewed from the following three stages in an ongoing process. The small club, for instance, still has some of the same functions, even though it now has new functions as a feeder club within a larger system of venues.

- 1993 - 1997: The small club grows new talent in the emerging gentrification of the Lower East Side

The Bowery Presents started on the Lower East Side in 1993 when gentrification was already happening (Abu-Lughod 1995), although not yet in the contemporary condition of generalized gentrification. The small club (Mercury Lounge) could evolve alongside other small clubs among a thriving scene of young artists and audiences. By working strategically with a large number of new bands, the company invested and developed its profile and reputation.

- 1997 - 2004: The mid-size club promotes talent to a broader audience within the context of accelerating gentrification

The opening of The Bowery Ballroom allowed the company to promote some of the artists to a larger audience, while touring headliner artists attracted a broader audience and more audiences from outside the neighborhood. This helped accelerate gentrification of the area and was a catalyst for a growing musical culture among the new urban middle-classes in both programming and venue design.

- Since 2004: Opening more venues to consolidate in a period of decline for other types of venues

The next moment of structural significance was the opening of more mid-size venues (Webster Hall in 2004 and Music Hall of Williamsburg in 2007) and large club venues (Terminal 5 and United Palace, both in 2007). With a system of venues from the small club to the mid-size venues and up, The Bowery Presents created a more extended internal career orbit for artists and gained a degree of monopoly status. At this stage, professional business management became a more important part of the company's activity, compared with the mid-1990s when most of the activity happened with young bands in Mercury Lounge.

A competitive market advantage was already achieved shortly after the first mid-size venue opened, as major record labels started moving showcase activities away from older venues such as The Bottom Line and into The Bowery Ballroom. The Bowery Ballroom is still a place where industry professionals from major labels and media companies explore the live performances of new talent in their field. They rarely go to smaller clubs or the Brooklyn warehouse spaces. During the same period, many established clubs closed, not just smaller ones such as Brownies (2002), CBGBs (2006), Knitting Factory (2009), and Tonic (2007), and with them a decline in the experimental art, jazz, and noise scene in Manhattan (Lee 2002). A significant narrative in the process is the closing of slightly larger venues with other cultural profiles, notably The Bottom Line (1974-2004) and Wetlands Preserve (1989-2001). The Bottom Line presented many jazz and world music artists over the years, for instance (Pareles 2004). Wetlands presented a number of African American funk and rock bands (Bill Bragin, personal communication, 30 March 2012). Among the remaining venues for such culturally diverse programming are Le Poisson Rouge, Joe's Pub, and Santos Party House. When the growth trend in venues for white rock bands promoted byThe Bowery Presents is viewed in the context of the decline of venues with a more culturally diverse booking, a picture emerges of increasing homogenization around white middle-class culture in Lower Manhattan. Another narrative in the process is modernization. The Bottom Line, for instance, maintained its cabaret-style design with 
a seated audience and did not adapt to a new generation of indie rock with standing audiences. Nor did the club's management create connections with the young rock bands that were performing in the new clubs on the Lower East Side. At the same time, the Bottom Line maintained a model of presenting an early and a late show by the same band, even though there were few audiences for the late show. Ultimately, the club closed and has not yet been re-opened (Pareles 2004; "The Bottom Line Website").

\section{Conclusion and Implications for Future Research}

The analytical narrative of this article is the main result of the research process and a key to understanding the argument and conclusions. It has therefore been necessary to explain how the narrative was developed through fieldwork and readings of the history and sociology of popular music in the city. The research process started with a search for objects in search of theory rather than theory in search of objects. In other words, the gentrification theme emerged through fieldwork and the realization of its explanatory power in the analysis and in the study of popular music and the city more generally. The first step in the process was to understand the evolution of popular indie rock concert clubs in New York during the 1990s, 2000s, and early 2010s. In my field research, I encountered a culture that was different from the descriptions of rock clubs and milieus in the existing literature and could not be satisfactorily explained by the conceptual approaches in this literature; approaches that were developed in relation to smaller clubs and other urban formations. In the process of organizing a narrative of the emerging explanations, I reviewed and developed knowledge in the specialized literatures on rock clubs and on popular music and gentrification.

The analytical narrative developed and illustrated in the case study of The Bowery Presents is grounded in a conception of gentrification as a broad social, economic, and cultural process in which social formations, including popular culture scenes and their organizational networks and markets, die out, change, but also emerge and in some cases continue to evolve after the neighborhood has gone through economic and demographic transformations and is no longer celebrated as a frontier of cool. If there is a "death of authentic urban places" (Zukin 2010), there is also a life of new places, even when these places are more generic and neutralized by global communications and the hypermobility of capital (Sassen 1998). The classic approaches in urban sociology in the Chicago tradition emphasize neighborhood dynamics and changing ecologies, and this offers a valuable perspective often lacking in the literatures on live music clubs and other cultural venues (Holt 2013). The main point of the present study, however, has not been to prove that change is happening within neighborhood dynamics but instead organize an analysis of particular relevance to the study of rock clubs in the condition of generalized gentrification. The focal points have evolved around the growth of mid-size concert venues and the market for popular indie rock among a new white middle-class population on the Lower East Side and later other neighborhoods and tourists in New York.

The fieldwork epiphany that structured the argument was how the dominant focus in the club literature on situated observations inside individual clubs could be complemented by analysis at the macro-levels of social and economic structural change. From this epiphany grew an understanding of the significance of entrepreneurialism, locations, market development, demographics, and consumer writing on Yelp. In a word, the sociological macro-level perspective proved useful because it provides knowledge of the conditions that shape dynamics in the micro worlds of individual venues but cannot be fully explained only from fieldwork observations or interpersonal encounters in the venues.

The article's contribution to the literature on popular music and gentrification follows from its conception of gentrification as a process rather than a discourse or a set of values among social types such as neo-bohemians, yuppies, or hipsters. The article 
discussed negative stereotypes of gentrification and how music scenes have constructed a discursive location for themselves outside of the gentrification process. Sociologists have argued since at least the early 1980s that spaces of culture create the precise kinds of symbolic value that gentrification feeds on. This pattern has been identified in the history of SoHo, Chicago's Wicker Park, and European cities such as Manchester, Liverpool, and Berlin. The pattern is weaker in the history of the rock scene on New York's Lower East Side, and the present study has focused on developments after the early phase of gentrification, particularly the development of a company that illustrates new patterns in musical and social life. The Lower East Side rock culture has become less about participating in a social scene and more about consuming professional art and entertainment. A rock concert culture evolved among the white middle-class populations that moved to the neighborhood in the $1980 \mathrm{~s}$ and 1990s, and it became more homogeneous and monolithic with the growing market dominance of The Bowery Presents in the mid-2000s. There are smaller developments that could be explored in future research, including the live music bars and small venues such as the Rockwood Music Hall that illustrates a somewhat different evolution in white middle-class culture of the Lower East Side. The evolution of the concert culture in mid-size venues, moreover, did not eliminate other social worlds for rock music. Underground sensibilities of the pre-gentrified Lower East Side of the 1970 s survive in cultural memory, particularly among audiences with experience of that scene and in the Brooklyn warehouse scene. Based on my interview material and hundreds of consumer reviews in social media applications, those underground narratives are generally absent from the culture at the mid-size venues of the Bowery Presents. Their audiences do not imagine a place outside gentrification. They approach the venue with a consumer perspective and have either not experienced the drastic changes or become insiders of the gentrified city and its workforce. It is in this perspective that we can speak of this indie rock concert culture as a music culture of the new middle-classes.

A particularly complex dimension of the analysis is collective psychology, particularly aesthetics and mentality. The transition from "gritty" to "cool" in the urban environment can be observed visually, physically, and geographically. Transformations of social and aesthetic categories such as "indie," and transformations in spirits of urbanism and capitalism in new social worlds, however, cannot be observed in the same way. Such aspects require hermeneutic work, and I would like to suggest in the following how this informed the organization of the article.

In the discourse analysis, distinctions were not mapped as static, disembodied structures, but rather as traces of cultural experience and mediations to understand the responses to cultural change in gentrification among participants and observes, including scholars. In the case study, observations of the evolution of The Bowery Presents served to describe the evolution of a new culture and to identify relevant analytical themes and categories that can be explored further in future research. There are themes in the existing literature on clubs that are still relevant, including identity and musical style, but collectivity has less importance in headliner-oriented mid-size venues compared with small community clubs. Moreover, the article indicates the relevance of new themes to be explored, particularly consumer service and entrepreneurialism, both for more knowledge of the experience in the venue and its place in urban life, but also for understanding its place in a wider trajectory of consumer culture and business history in post-industrial society. The case of the indie rock concert business and gentrification in New York is part of the broader history of how practices in conventional business domains of society have increasingly spread to other domains of society, from culture to the education system and beyond to the humanitarian sector. In all these domains, consumption, marketing, and service have increasingly become global ideologies (Baumann 2007; Zwick and Cayla 2012; Thrift 2005). More research can be done on the particular developments in popular music 
culture. The commercial development of indie rock business in New York, for instance, differs significantly from conventional accounts of "cool capitalism" or "indie capitalism" in some respects. While my research on perceptions of the venue experiences among both consumers and industry professionals suggests that The Bowery Presents is associated with a kind of cool entrepreneurial spirit and with indie aesthetics vis-à-vis Live Nation's corporatism and mass culture formats, the cultural profile of The Bowery Presents is far from the epitome of cool capitalism in the advertising culture of Pepsi and Red Bull. Now that cool has become a popular element in the emotional language of capitalism (McGuigan 2009), conventional forms cool and other signifiers of authenticity in popular music cultures change, and this might explain how audiences perceive rock music history and live music venues. There is no advertising in the venues of The Bowery Presents, and the indie rock headliners tend to keep any arrangements with corporate sponsors "backstage" (as opposed to publicly associate themselves with brands). The Bowery Presents exemplify a relatively classic culture in the music business, one that refines the existing format of the rock club concert in buildings with a unique historical aura and does not adopt rhetorics of novelty, difference, or youth culture. The music programming has strong retro elements. Thus, this article opens up wider perspectives for future research in the history and sociology of live music and popular culture.

I would like to end by offering a cultural critique based on the analysis above. The analysis suggests that the conditions of artistic creativity and performance have changed in the process of gentrification. As artists can no longer afford to live on the Lower East Side or in Williamsburg, they do not live in the neighborhood where the clubs are. This creates a spatial separation between the sites of public performance and everyday life. We have noted this trend on the audience side, and it has social implications because it detaches musical creativity from neighborhood ecologies. It also creates an increasing dependence on blogs, showcase festivals, and of touring bands eager to play in New York.

If spaces of artistic and social experimentation have shrunk in the center of New York and other cities, this might have negative consequences for artistic innovation and for human life. Artistic experimentation, not just any creativity, has unique values and is unique to humanity (see, e.g. Blacking 1973). So while there is little future in decrying the loss of a particular cultural scene that cannot be preserved, there is a need for changing the conditions for future cultures to grow. The experience of my informants suggests that the urban experience is still important and a vital element in their media culture. One example that might suggest how the conditions of urban public life have changed, and specifically the conditions of public gatherings without money capital, is the Occupy Wall Street movement. The movement used social media from the beginning, but clearly attempted to take root in urban space and target protests near Wall Street. However, in a city where only few spaces are left for people without money, the camp in Zuccotti Park quickly became a magnet for homeless people, and this eventually contributed to its decline. Participants felt that practical issues related to the homeless came to overshadow the political issues. The police prevented the movement to take root in other public places, and the political dimension of this movement might make visible just how much the autonomy of social scene interaction has been limited by institutionalized forms of commercial control. Without a certain level of autonomy from institutions and markets, neither social movements nor art forms will have the site-specific social energy so crucial for a vibrant culture. More artistic development will happen in spaces further away from the city and in the virtual world, but without the socio-material encounter in the city, some of the intensity is lost that can only be regained by changing the urban condition. Otherwise, the city will evolve further as a place of perfected distribution and service and not a vital site of artistic production. 


\section{Endnotes}

1 For an understanding of venues as nodal social institutions, see Hannerz (1980, 54).

2 The following interviews with professionals were particularly important: Jason Foster, 6 January 2010; Kate Landau, 27 April 2010; Lio Kanine, 20 April 2010; Rob Harvilla 16 April 2010; Ariel Panero 23 April 2010; Rami Haykal 27 April 2010; B.Q. Nguyen 24 March and 1 April 2012; Bill Bragin 30 March 2012; Garrett Brooks 18 November 2012; Laura Wasson 10 March 2013, and three others who prefer to remain anonymous.

3 Young indie bands and their entrepreneurial managers, moreover, ascribed importance to the concentration of bloggers, online editors, and website designers in Brooklyn (Simon Henderson, personal communication, 10 April 2010; Eric Lodwick and Drew Robinson, 20 April 2010).

4 These figures for the general capacity range of small- and mid-size clubs are based on my research on industry terminology and perceptions among informants in New York, but the same distinctions apply to the rock club scenes in Berlin and London, for instance. The categories are not universal, however.

${ }^{5}$ The transition from an ethnically diverse area with many low-income residents to a white middle-class population on Lower Manhattan is striking in the visual illustration provided by the United States Bureau of Census (Bloch, Carter, McLean 2012).

6 A similar discourse was articulated around the closing of the Bottom Line ("The Bottom Line Website;" Pareles 2004). The discourse has been articulated almost daily on popular blogs such as the Brooklyn Vegan and by promoters such as Todd Patrick and Ariel Panero (personal communication with Ariel Panero, 23 April 2010; Todd Patrick, 27 April 2010).

7 To his credit, Sisario did write about structural changes the following year, observing the new centrality of mid-size venues, for instance, but he did not make the connection to gentrification (2007). Music critics generally still continue to talk about gentrification in narratives of decline.

8 Zukin mentions Todd Patrick and writes briefly about the park (2010, 43-44), but she does not account for the evolution of the shows and the reactions to the development among the indie rock scene. One of my main informants here was the now deceased indie promoter Ariel Panero, who organized many shows with his small organization "Less Artists More Condos" and talked about promoting shows at the Jelly pool parties in 2010.

9 The term baby band generally refers to young bands still on the learning curve (see, e.g., Pareles 2013).

10 The term feeder club is also used in sports in a similar sense of a junior team that primarily serves to grow talented players and feed them directly into the organization's parent club at the top level. I am indebted in my account of Mercury Lounge to Bill Bragin, former manager of Joe's Pub and now director of public programming at Lincoln Center. Bragin collaborates with big players such as The Bowery Presents and Live Nation (Bill Bragin, personal communication, 30 March 2012)

11 As some of their artists have grown in popularity, The Bowery Presents has continued to open larger clubs and moved even further by presenting the most popular arts in large theatres and even Madison Square Garden. The number of shows in large theatres and arenas increased after Jim Glancy, formerly the local president of Live Nation, joined The Bowery Presents in 2004 and brought some of his artists with him. 


\section{Acknowledgements}

I would like to express special gratitude to Chris Washburne, Francesco Lapenta, Jim Sykes, and Shannon Garland for their help during the research that led to this article. I would also like to thank Ariel Panero, Bill Bragin, B.Q. Nquyen, Edan Wilbur, Jason Foster, Kate Landau, Lio Kanine, Matt Convoy, Melena Ryzik, Rami Haykal, Rich Zerbo, Rob Harvilla, Simon Henderson, Travis Johnson, and audiences at the venues of The Bowery Presents and in Brooklyn DIY spaces such as Monster Island Basement, Market Hotel, and Death by Audio. I am most grateful to the anonymous reviewers and to Simone Krüger for her ongoing editorial support and William Echard for final cpy-editing. Thanks also to editorial team members Elina Hytönen- $\mathrm{Ng}$, Rupert Till and Hillegonda Rietveld. Valuable comments on late drafts of the article also came from Mark Banks, Monique Ingalls, and Nick Prior.

\section{References}

2010 Demographic Profile Data. The United States Census Bureau, http://factfinder2.census.gov/faces/tableservices/isf/pages/productview.xhtml?pid=D EC 10 DP DPDP1 Accessed: 10 Apr. 2013.

Abebe, N. (2010) The Decade in Indie. 25 February 2010, http://pitchfork.com/features/articles/7704-the-decade-in-indie/ Accessed 13 May 2012.

Abu-Lughod, J. -

(1995) From Urban Village to East Village: The Battle for New York's Lower East Side. Oxford: Backwell.

(1999) New York, Chicago, Los Angeles: America's Global Cities. Minneapolis: University of Minnesota Press.

Albini, S. (1993) The Problem with Music. The Baffler No. 5. http://web.archive.org/web/20061115070529/http://www.thebaffler.com/albiniexcerpt html Accessed: 9 Nov. 2011.

Atkinson, R. and G. Bridge, Ed. (2005) Gentrification in a Global Context: The New Urban Colonialism. London and New York: Routledge.

Baumann, Z. (2007) Consuming Life. Cambridge: Polity.

Beck, L. (2012) Ten Years of Parts \& Labor, Through the Eyes of Their Four Drummers. The L Magazine. http://www.thelmagazine.com/newyork/parts-andlabor/Content?oid=2214280 Accessed: 15 May 2012.

Becker, H. (1998) Tricks of the Trade: How to Think About Your Research While You Are Doing It. Chicago: University of Chicago Press.

Berger, H. (1999) Metal, Rock, and Jazz: Perception and the Phenomenology of Musical Experience. Middletown, Connecticut: Wesleyan University Press.

Blacking, J. (1973) How Musical Is Man?. Seattle and London: University of Washington Press.

Bloch, M., S. Carter, and McLean A. (2012). Mapping American: Every City, Every Block. http://projects.nytimes.com/census/2010/explorer Accessed: 8 May 2012.

Charnas, D. (2010) The Big Payback: The History of the Business of Hip Hop. New York: Penguin.

Cohen, S. -

(1991) Rock Music in Liverpool: Popular Music in the Making. Oxford: Oxford University Press.

(2007) Decline, Renewal, and the City in Popular Music Culture: Beyond the Beatles. Aldershot: Ashgate.

Currid, E. (2007) The Warhol Economy. Princeton, N.J: Princeton University Press. 
Fischer, C. S. (1995) The Subcultural Theory of Urbanism: A Twenty-Year Assessment. American Journal of Sociology 101 (3): 543-577.

Florida, R. -

(2002) The Rise of the Creative Class: And How It's Transforming Work, Leisure, Community and Everyday Life. New York: Basic Books. (2005) The Flight of the Creative Class. New York: Harper Collins.

Fox, A. (2004) Real Country: Music and Language in Working-Class Culture. Durham and London: Duke University Press.

Gann, K. (2006) Music Downtown: Writings from the Village Voice. Berkeley: University of California Press.

Garcia, L-M (2013) Crowd Solidarity on the Dance Floor in Paris and Berlin. In: Musical Performance and the Changing City: Post-Industrial Contexts in Europe and the United States, edited by F. Holt and C. Wergin. New York and London: Routledge, pp. 227-255.

Gendron, B. (2002) Between Montmartre and the Mudd Club: Popular Music and the Avant-Garde. Chicago: University of Chicago Press.

Goodman, L. (2013) Get Yer Yeah Yeah Yeahs Out. New York Times, 29 March 2013, http://www.nytimes.com/2013/03/31/magazine/get-yer-yeah-yeah-yeahsout.html?ref=magazine\& $r=0$ \#commentsContainer, accessed 11 April 2013.

Grazian, D. -

(2003) Blue Chicago: The Search for Authenticity in Urban Blues Clubs. Chicago:

The University of Chicago Press.

(2008) On the Make: The Hustle of Urban Nightlife. Chicago: The University of Chicago Press.

Hammett, J. and K. Hammett (2007) The Suburbanization of New York: Is the World's Greatest City Becoming Just Another Town? New York: Princeton Architectural Press.

Hannerz, U. (1980) Exploring the City: Inquiries Toward an Urban Anthropology. New York: Columbia University Press.

Hebdige, D. (1979) Subculture: The Meaning of Style. Routledge: London and New York.

Hesmondhalgh, D. (2005) Subcultures, Scenes or Tribes? None of the Above. Journal of Youth Studies 8 (1): 21-40.

Holt, F. (2013) The Advent of the Rock Clubs for the Gentry: Berlin, Copenhagen, and New York. In F. Holt and C. Wergin, Ed. Musical Performance and the Changing City: Post-Industrial Contexts in Europe and the United States. New York and London: Routledge: 153-177."

Keith, M. (2005) After the Cosmopolitan? Multicultural Cities and the Future of Racism. New York: Routledge.

Kozak, R. (1988) This Ain't No Disco: The Story of CBGB. Boston and London: Faber and Faber.

Lee, D. (2002) Neighborhood Report: New York Up Close; Rock Alternatives: A Music Scene Migrates to Brooklyn. The New York Times. http://www.nytimes.com/2002/08/04/nyregion/neighborhood-report-new-york-upclose-rock-alternatives-music-scene-migrates.html Accessed: 2 May 2012.

Lawrence, T. (2004) Love Saves the Day: A History of American Dance Music Culture 1970-1979. Durham, N.C. Duke University Press.

Levine, L. (1988) Highbrow / Lowbrow: The Emergence of Cultural Hierarchy in America. Cambridge, MA: Harvard University Press. 
Lloyd, R. (2006) Neo-Bohemia: Art and Commerce in the Postindustrial City. New York and London: Routledge.

McGuigan, J. (2009) Cool Capitalism. London: Pluto.

McKinley, J. (2012) Underground Musicians Lose a Haven. New York Times, 11 September 2011, http://www.nytimes.com/2011/09/12/arts/music/monster-island-toclose-and-underground-clubs-lose-a-haven.html? $r=1$ \&pagewanted=all Accessed: 15 May 2012.

McRobbie, A. (2002) Clubs to Companies: Notes on the Decline of Political Culture in Speeded Up Creative Worlds. Cultural Studies 16 (4): 516-531.

Mele, C. (2000) Selling the Lower East Side: Culture, Real Estate, and Resistance in New York City. Minneapolis: University of Minnesota Press.

Merriam, A. and R. W. Mack (1960) The Jazz Community. Social Forces 38 (3): 211 222.

Methos, Z. (2005) Celebrities and Others Urge NYC to Declare CBGB an Official Landmark. BC blogcritics, Music, http://blogcritics.org/music/article/celebrities-andothers-urge-nyc-to/ Accessed 4 May 2012.

Nasaw, D. (1993) The Rise and Fall of Public Amusements. Cambridge, Mass.: Harvard University Press.

O’Meara, C. P. (2007) 'The Bush Tetras, 'Too Many Creeps,' and New York City. American Music Summer. 193-215.

Pareles, J. (2004) The Bottom Line, A Place Where the Music Always Came First. New York Times, 24 January 2004, http://www.nytimes.com/2004/01/26/arts/critic-snotebook-the-bottom-line-a-place-where-the-music-always-camefirst.html?src=pm Accessed: 17 November 2011.

(2013) Selling Stars, Brands, and Baby Bands. New York Times, 17 March 2013, http://www.nytimes.com/2013/03/18/arts/music/selling-stars-brands-and-babybands.html?pagewanted=all Accessed 10 April 2013.

Phillips, A. (2007) Lollapalooza Report: Sunday. Pitchfork.com, http://pitchfork.com/news/27360-lollapalooza-report-sunday-amy-phillips/ Accessed: 11 April 2013.

Reynolds, S. (2005) Rip It Up and Start Again: Postpunk 1978-1984. London: Faber and Faber.

Rose, T. (1994) Black Noise: Rap Music and Black Culture in Contemporary America. Middletown, Connecticut: Wesleyan University Press.

Sassatelli, R. (2010) Fitness Culture: Gyms and the Commercialisation of Discipline and Fun. New York: Palgrave MacMillan.

Sassen, S. -

(1991) The Global City: London, New York, Tokyo. Princeton, N.J.: Princeton University Press.

(1998) Globalization and Its Discontents: Essays on the New Mobility of People and Money. New York: The New Press.

Shank, B. (1994) Dissonant Identities: The Rock'n'Roll Scene in Austin, Texas.

Middletown, Connecticut: Wesleyan University Press.

Shaw, W. S. (2007) Cities of Whiteness. Malden, MA: Blackwell.

Shulman, R. (2005) Never Trust a Punk Club Over 30? The Past May Not Save CBGB for Long. New York Times, 5 August 2005, http://www.nytimes.com/2005/08/05/nyregion/05cbgb.html Accessed 4 May 2012. 
Sisario, B. -

(2006) Where the Beat Goes On. New York Times, 27 October 2006, http://select.nytimes.com/gst/abstract.html?res=FA0D12F93F5B0C748EDDA909 94DE404482 Accessed 17 April 2013.

(2007) A Small Strategy for Selling Concerts. New York Times, 7 June 2007, http://www.nytimes.com/2007/06/07/arts/music/07bowe.html?ref=music Accessed 1 May 2012.

(2008) It's Been Quite a Pool Party, but the Days Grow Short. New York Times, 1 August 2008, Accessed http://www.nytimes.com/2008/08/01/arts/music/01pool.html?pagewanted=all

Smith, A. L. (2010) The Verge Q+A: Punk Pioneer Steve Albini on Music Festivals, The Future of Radio and Why He Wants GQ To Fail. GQ, 29 September 2010, http://www.gq.com/blogs/the-q/2010/09/steve-albini.html Accessed: 9 November 2011.

Smith, N. (2002) New Globalism, New Urbanism: Gentrification as Global Urban Strategy. Antipode 34 (3): 440.

Smith, N. and P. Williams (1986) Gentrification of the City. Boston, Mass. and London: Allen \& Unwin.

St. John, G. (2009) Technomad: Global Raving Countercultures. Equinox: London.

Terkel, S. (1967) Division Street: America. New York: The New Press.

The Bottom Line Website. http://www.bottomlinecabaret.com/ Accessed: 8 May 2012.

The end of TONIC.... (2007) A thread started by digital_freak in Flickr group "experimental LIVE music," http://www.flickr.com/groups/tonicnyc/discuss/72157600055703202/ 7 April 2007, Accessed: 4 May 2012.

Thornton, S. (1995) Club Cultures: Music, Media, and Subcultural Capital. Cambridge: Polity.

Thrift, N. (2005) Knowing Capitalism. London: Sage.

Washburne, C. (2008) Sounding Salsa: Performing Latin Music in New York City. Philadelphia: Temple University Press.

Zukin, S. -

(1982) Loft-Living: Culture and Capital in Urban Change. Baltimore, Maryland: John Hopkins University Press.

(1995) The Cultures of Cities. Oxford: Blackwell.

(2010) Naked City: The Death and Life of Authentic Urban Places. Oxford and New York: Oxford University Press.

Zwick, D. and J. Cayla, eds. (2012) Inside Marketing: Practices, Ideologies, Devices. Oxford and New York: Oxford University Press. 